Jonathan Simon ${ }^{\star, a}$

\title{
A Funded Experience: Selznick's Vision of JSP and the Unfinished Agenda of the Interdisciplinary Movement in Legal Education
}

\author{
*Corresponding author: Jonathan Simon, Adrian A. Kragan Professor of Law, University of \\ California, Berkeley, CA, USA, \\ e-mail: jsimon@law.berkeley.edu
}

\section{Introduction. Law and Society in Moral Context}

The late Philip Selznick was one of the leading sociologists of the $20^{\text {th }}$ century and a founder of the modern law and society movement. At Berkeley, where he taught from 1958 until his retirement in 1982, Selznick created two institutions that are taken to be emblematic of the rise of law and social science and the interdisciplinary study of law: in the last third of the $20^{\text {th }}$ century, the Center for the Study of Law \& Society (founded in 1961); and, with Law Dean Sanford Kadish, the Jurisprudence and Sociology program (JSP), in 1977. ${ }^{1}$ Today, amidst signs that Oliver Wendell Holmes' famous prediction that law would eventually belong to "the man of statistics and the master of economics" 2 is being realized (more than a century after he made it), Selznick's vision for JSP is a reminder of the untapped potential of what we may call the "interdisciplinary movement" in law, for transforming the preparation of law students for practice and professional life, and of reconstructing graduate preparation for academic careers in law.

Selznick deserves recognition along with other members of his generation for laying the groundwork for the success that interdisciplinary scholarship has had in American legal education since the 1970s, but we should also recognize those parts of his legacy that constitute a distinctive (and indeed minority) strain within the broad landscape of post-Realist legal scholarship. While Selznick embraced the emerging consensus that law be understood in its social

a Adrian A. Kragen Professor of Law, UC Berkeley

1 The program was approved by the University in 1975 and accepted its first class in 1977.

2 Oliver Wendell Holmes, The Path of the Law, 10 Harv. L. Rev. 457 (1897). 
context, JSP in particular was envisioned by Selznick to be much more than a "law and society" or even a "law and social science" program; both in its commitment to the substantive insights of the humanities (about human values) and to problem oriented scholarship and curriculum. JSP's success as a doctoral program both in producing academics for research grade universities in the U.S. and globally (e.g., the U.K., Israel, Australia, Canada) and as a platform for interdisciplinary legal scholarship of considerable prestige, owes a great deal to these aspects of Selznick's vision which have been neither widely admired nor copied. I call these a "funded experience" to echo the term Selznick derived from American philosopher John Dewey to designate those intangible but crucial elements of social institutions that come from the lived experience of people who come together in those institutions. ${ }^{3}$ Selznick believed that legal teaching and scholarship needed to draw more explicitly on those funded experiences, an ambition at the heart of JSP, but his vision for JSP is also a funded experience from which the we might renew the work of clarifying the values at stake in the triumph of interdisciplinary law.

In his contribution to the California Law Review's welcome symposium for the JSP program, ${ }^{4}$ Selznick sketched out his hope and vision for the program; one he made clear was a personal rather than corporate or collective one. ${ }^{5}$ Here his distinctive vision was given full (if typically understated) treatment. A number of elements of JSP mark clear divergences from the broader trends both in universities within the consensus law and society vision: his interest in maintaining a space for values, including justice, in the curriculum; his commitment to a full spectrum interdisciplinarity that included not just law and the social sciences, but the humanities as well; and his commitment to a problem centered approach to social science as opposed to a variety of social science theory building projects associated with such leading $20^{\text {th }}$ century figures as Talcott Parsons and Robert King Merton.

This essay argues that Selznick's vision for JSP at the end of the 1970s remains a promising and largely untapped guide for realizing the promises and avoiding the perils associated with the success of the interdisciplinary turn inside the legal academy since 1980 and to realizing the greatest gains for the broader university and society. Then it appeared that the social sciences were on their way toward shedding the disciplinary exoskeletons that had organized university education

3 Richard Bernstein, John Dewey's Metaphysics of Experience, 58 J. Phil. 5, 13 (1961).

4 Philip Selznick, Jurisprudence and Social Policy: Aspirations and Perspectives, 68 Cal. L. Rev. 206 (1980).

5 Although undeniably the leader of the sociological group that included future Berkeley Law faculty members Jerome Skolnick. Sheldon Messinger, Philippe Nonet. 
since the end of the $19^{\text {th }}$ century in favor of interdisciplinary approaches such as James March's design for the School of Social Ecology at UC Irvine. ${ }^{6}$ Indeed, the biological sciences, still vested in shells like zoology, botany, and biology morphed in the following decade into the "life sciences" with distinctions of scale (ecologies to molecules) and research focus rather than disciplines. But the social science disciplines have resisted realignment and strengthened their hold on education and publishing. ${ }^{7}$ Since the 1990s it has been law schools, (along with schools of business, health, and welfare), ${ }^{8}$ have become the more effective vehicles for organizing interdisciplinary research and teaching collaboration. However, for law schools, the transition has occasioned considerable anxiety about the value of interdisciplinary research to the teaching mission of preparing students for careers in and around the law. ${ }^{9}$

In ways that would have been very surprising in 1980, interdisciplinarity has become an implicit but unstable framework in leading American law schools, most of which now consider it essential to have a faculty composed largely (although not exclusively) of $\mathrm{PhD}$ holders in disciplines like economics, sociology, political science, and philosophy (as well as history, psychology and many other fields). ${ }^{10}$ While successful in transforming academic credentials in the legal field, the implicit interdisciplinarity has been under periodically fierce attack since at least the early 1990s when a liberal federal judge, Harry Edwards, raised pointed questions about relevance of interdisciplinary scholarship then becoming more common in the law reviews of the top schools to judges and other core actors in the legal system. ${ }^{11}$ More recently the criticism has spread from scholarship to pedagogy. Law faculties who during the boom years since the early 1990s have invested heavily in interdisciplinary scholars and scholarship, stand accused at

6 A. Binder, D. Stokols, \& R. Catalano, Social Ecology: An Emerging Multidiscipline, Envtl. Educ., 7, 32-43 (1975).

7 This may reflect the underlying uncertainty about many of its most important concepts, rationality, legitimacy, as well as the proper units of analysis.

8 For a variety of reasons that are beyond the scope of this essay, law schools have been more influential in this regard than schools of health and welfare. The comparison with business schools is less clear to this author. In many respects business schools seem to have developed an even more successfully integrated model of interdisciplinarity in their curriculum than law schools.

9 As will be discussed further below, concerns about the adequacy of professional skills education have been conflated with interdisciplinarity even though the two are actually importantly related. See, Kristin Holmquist, Challenging Carnegie, 61 J. Legal Educ. 353 (2012). 10 In contrast, in the UK and much of Europe, doctoral degrees are becoming a common credential for law teachers, but doctoral degrees in law, not in the disciplines.

11 Harry Edwards, The Growing Disjunction Between Legal Education and the Legal Profession, 91 Mich. L. Rev. 34 (1992). 
a time of great economic uncertainty of having under-invested in curricular elements relevant to preparation for practice. ${ }^{12}$

To be sure, this critical perspective has major flaws in it. For anyone who attended a university based law school in the 1980s or earlier, the question of relevance to the skills of lawyering of the doctrine based scholarship and teaching of that time were very much in question. Duncan Kennedy famously discerned the wisdom in the elite law training he had witnessed as both student and professor as a form of obscurantism designed to make a relatively straightforward topic complex enough to do the real work of elite legal education, that is select and sort cohorts of lawyers for elite firms and government service. ${ }^{13}$ If the current braiding of interdisciplinary scholarship into teaching (as evidenced by any major casebook on any subject) is unhelpful to lawyering it is unlikely to be more so than its predecessors. ${ }^{14}$ But the truth behind the frequently recycled condemnation of interdisciplinarity in law schools is that it has not tried hard enough to escape the stranglehold of the old curriculum..$^{15}$ Selznick's vision continues to provide key insights for creating the compelling case for why this curriculum really matters to the education of lawyers, the absence of which remains a serious vulnerability in the emerging law school.

Even among those with doctoral degrees from the social sciences and humanities who have benefitted from the opening of a space for interdisciplinarity within academic law, there is a strong discomfort with interdisciplinarity itself. This explains why despite enjoying a strong reputation and an excellent record for placing its students, the JSP program has not been much imitated. ${ }^{16}$ Recent experiments in law school based academic doctorates have opted instead

12 This critique has been sharpened by the Great Recession, rising competition in the market for legal services and law school tuitions that, like academia in general, have risen far faster than most other prices. See, David Segal, What They Don't Teach Law Students: Lawyering, N. Y. Times, November 19, 2011, available at http://www.nytimes.com/2011/11/20/business/ after-law-school-associates-learn-to-be-lawyers.html?_r=1\&scp=6\&sq=law\%20schools \&st=cse; see also Stanley Fish, The Bad News Law Schools, N. Y. Times, February, 20, 2012, available at http://opinionator.blogs.nytimes.com/2012/02/20/the-bad-news-lawschools $/$ scp $=2 \& \mathrm{sq}=$ law\%20schools\&st=cse.

13 Duncan Kennedy, Legal Education and the Reproduction of Hierarchy (1983).

14 Which is not to say that some law students would not benefit from the links to the practicing bar that a more practice dominated faculty might produce, at least in local and regional markets.

15 This was reflected in David Segal's New York Times article in quotes from former Vanderbilt Dean Edward Rubin, on the difficulty of leading the faculty through a major effort to revise the first year curriculum.

16 Perhaps the closest was the Institute for Law \& Society, founded at NYU in 1995 with joint sponsorship by the NYU Law School and the School of Social Science and closed in 2010. 
for a variety of structures more accommodating to the existing disciplinary structures - generally with economics as the focus, or with a series of joint programs between the school of law and various, typically social, science departments. Rereading Selznick is a reminder of what is at stake in creating a truly broad intellectual community around the fundamental problems of jurisprudence. A program that requires scholars from different disciplinary traditions to engage repeatedly across a set of overlapping interests risks incoherence or balkanizing into small program-lets, but it offers a distinctive kind of payoff in the intellectual climate it produces for its students. These are payoffs, I believe, that law schools are uniquely well positioned to capture.

Thirty-two years after Selznick published his "aspirations and perspectives" on the JSP program, and two years after his death, these aspects of Selznick's spirit have yet to leave the building; but their future, even at Berkeley, is in question. If his commitment to the rigorous study of values, to deep interdisciplinarity, and to problem centered pedagogy and research cannot thrive at Berkeley, it is unlikely to survive anywhere else. If, on the other hand, its role in producing Berkeley Law's emerging model of legal education and scholarship can be clarified and strengthened, Selznick's ideas can be a resource for a new wave of innovation in graduate legal education.

\section{Space for Justice in the School of Law}

The dominant jurisprudential perspective in elite law schools of the 1970s, associated with the legal process school and positivism, held that the essential and effective features of a legal system could be adequately defined and understood without recourse to substantive values like justice. ${ }^{17}$ Selznick seemed to concede a great deal to this reigning legal process positivism of his time when he observed that "we have a School of Law, not a School of Justice." 18 However, Selznick was clear that he saw JSP not as a direct challenge to this dominant paradigm, but as

17 The iconic statement of this debate at the time of JSP's founding was the Hart-Fuller debate over the legality of Nazi law. See, Lon L. Fuller, Positivism and Fidelity to Law - A Reply to Professor Hart, 71 Harv. L. Rev. 630 (1958); H.L.A. Hart, Positivism and the Separation of Law and Morals, 71 Harv. L. Rev. 593 (1958).

18 Selznick, supra note 4 at 211 . In contrast, schools of justice were being created at a number of universities in the 1980 s with an eye toward the same general territory of the nonprofessional study of law including problems of criminal justice. They were located outside of traditional law schools, and could be seen, at least aspirationally as competitors at a time when movements like Alternative Dispute Resolution (ADR) and a variety of informal justice 
a supplement. JSP represented real space opened up within the school of law so defined, space for the study of justice and other values like democracy, liberty, or equality. Speaking directly to skeptical colleagues at Boalt Hall wary of a program dealing explicitly with "social policy" in the 1970 s when there were already serious tensions within law schools over the proper boundaries of using the legal system, to achieve Dr. King's vision of social justice or Milton Friedman's, Selznick wrote ${ }^{19}$ "[w]e have gotten along fairly well despite sustained debate on the concept of law. So too with justice."20

Restating in neutral terms the central pedagogic dogmas of the time, Selznick observed that students upon entering those schools must learn to think like lawyers, and above all that means learning how to "distinguish his own sense of justice and his own way of reasoning from the kind of argument that will carry weight in court." 21 Their quest for justice must be subordinated to and accomplished through their achievement of "legal professionalism." Selznick observed however that this pedagogy carries with it a danger. In the largely successful effort to separate the student from his or her own intuitive sense of justice, "many students come to believe that justice and law are at least roughly equivalent or, on the other hand, that justice is a distant, ineffable ideal whose relation to law is at best tenuous."22 Either result means a view of law (and lives in the law) for which the possibility of justice holds out little redemptive potential, and in which that potential can play little role in creatively testing, criticizing, and reforming the law.

Without questioning the legal process focused aspirations of the 1970s curriculum, Selznick argued that "legal scholarship and legal education ought to be more explicitly committed to studying justice as well as law." Yet this typi-

expressions, vied with public courts to create more "access to justice" to the large portions of American society locked out of success. At Berkeley where the creation of JSP was in part a channeling of resources that had formerly composed a "school of criminology" controversially closed down in the 1970s, the placement of JSP in and under the authority of the school of law was seen as a conservative move, embedding the critical aspects of research so evident in the criminology schools later years in a setting characterized by respectful service to the enterprise of reforming American law and preparing excellent lawyers.

19 A distinctive mash-up of social justice and public policy, "social policy" would have called up topics like school desegregation and funding equalization, the latter especially here in California where colleagues like Stephen Sugarman and John Coons litigated on behalf of equalizing school funding.

20 lbid.

21 lbid.Elizabeth Mertz's empirical research on the language of law school teaching suggests that this has remained central at least through the 1990 s when her data was collected. See, Elizabeth Mertz, The Language of Law (2009).

22 Selznick, supra note 4 at 211. 
cally modest proposal contained an expansive potential. Limited to the study of "disembodied abstraction" as it was in the standard curriculum's courses legal ethics, or jurisprudence, the study of justice might remain incapsulated. For Selznick, however, this meant not just analysis of conceptual artifacts as in the philosophical study of justice, but also the close study of "empirical contingencies, processes, and outcomes." ${ }^{23}$ If, however, as Selznick suggested in his essay, studying justice means accessing the meaning created by the lived experience and struggles of people who come to law seeking justice, it is a project that can spread to every section of the curriculum and beyond its traditional borders. Indeed, "as a product of experience, it cannot have clear boundaries."

The aim was to produce an "experience" in "studying law" that includes an encounter with the "values at stake in legal experience." JSP's graduate curriculum, which in the 1980s included courses dealing with the social and political consequences of civil rights law, the transformations in criminal law associated with the war on crime, and the judicialization of politics, then, was intended from the start as a dual-use curriculum. For a small group of doctoral students, it would form the core of a unique interdisciplinary curriculum aimed at producing scholars of justice for the social sciences and humanities, and it would provide JD students with an analytical and critical path back to the lived experience of those mobilizing or being mobilized by law in pursuit of justice.

As an agenda for legal scholarship, Selznick's vision for JSP reflected a broader turn in the legal academic field away from scholarship primarily concerned with "positive law - how to find it, how to reconcile its elements, how to criticize it from within, how to apply it in particular "fact situations"' ${ }^{4}$ towards scholarship concerned with "empirical contingencies, processes, and outcomes." 25 But as pedagogy, Selznick's vision for JSP presaged a turn in the focus of classes away from mapping legal territories and toward being defined by problems of justice and injustice; courses, for example, not just on "family law" but on "domestic violence," not just on "criminal procedure" but on "mass incarceration" and "restorative justice." This is also true of the new generation of clinics, at Berkeley Law and other law schools, which combine traditional goals of expanding access to justice with policy and knowledge advocacy.

23 Selznick, supra note 4 at 212.

24 lbid., at 210-11.

25 lbid. Often today the description "normative" is applied to describe legal scholarship as opposed to more "positive" approach favored by social sciences. Note that these distinctions are orthogonal (cut across) the distinction between positive law and justice. 
Today, nearly 40 years after Selznick's ideas about JSP took shape, the idea of curriculum shaped around problems of jurisprudence and social policy is more relevant to a generation of law students for whom the ability to combine traditional legal skills of research, analysis, advocacy and negotiation with practical sophistication empirical methods and social science theory and findings will be increasingly advantaged in seeking jobs in business, government, and in social justice work. Criminal law provides a good example. In the 1970 s the revolution in criminal procedures started by the Warren Court and continued by the Burger Court seemed to demand lawyers capable of presenting empirical evidence to courts. ${ }^{26}$ But the war on crime and the turn toward neoclassicism and incapacitation in criminal law checked the drift toward empirical lawyering. The increasing power of prosecutors under determinate sentencing and harsh new enhancement statutes rendered the kind of policy lawyering anticipated by the Warren Court unavailing as the question of cooperation became overwhelming. ${ }^{27}$ The regularity with which conviction means incarceration also hollowed out the role of defense lawyers as brokers of information about meaningful programs in the community around which some kind of probation, civil injunction, or risk reducing program might be negotiated. The decisions of the later Burger and Rehnquist Courts reinforced the return to a focus on technical procedures. ${ }^{28}$

But in recent years there have been clear signs that reform of criminal justice will require advocates with sufficient empirical sophistication to manage an increasingly wide range of options following arrest. Indeed the huge buildup in correctional populations under the prevailing "tough on crime" ethos with its populist rejection of expert knowledge, have now created fiscal and legal challenges to state prison systems that are forcing states to find innovative alternatives to incarceration and placed a premium on criminological knowledge among criminal justice actors including lawyers. The Supreme Court's decision in Brown v. Plata, ${ }^{29}$ requiring California to reduce overcrowding significantly, has led the state to announce a major "realignment" away from state prison as the penalty of choice for many minor felonies and toward county level jurisdiction and alternatives to incarceration. The full implications of this policy shift are not clear, but its success depends on the ability of county level justice agencies to wield exper-

26 Jonathan Simon, Katz at 40: A Sociological Jurisprudence Whose Time Has Come, 41 U.C. Davis L. Rev. 935 (2007).

27 William Stuntz, The Collapse of American Criminal Justice (2010).

28 For example, the Court's equal protection decisions rejected statistical data in the areas in which it was most crucial, such as capital punishment. McCleskey v. Kemp, 481 U.S. 279 (1987).

29 09-1233 May 23, 2011-1 (Slip Opinion), October Term, 2010. 
tise beyond the law narrowly conceived in order to identify felons whose risks to public safety can be effectively managed without recourse to incarceration. Nationally, a whole host of problem solving courts have emerged, including drug courts and behavioral and mental health courts where charges may be resolved by successfully developing a therapeutic plan to keep defendants out of drug addiction, untreated mental illness or homelessness. ${ }^{30}$ In the aftermath of America's imprisonment binge, driven in large part by sentencing laws that give prosecutors great discretion to determine how long prisoners will serve, new assistant prosecutors will increasingly be valued for their ability to help the office assess the risk posed by defendants whose decades in prison are likely to cost taxpayers millions.

Civil justice offers potentially even more social gains if empirical research methods and theory can help shape innovative strategies to open up access to justice for disputes that currently express themselves as crimes or in self-imposed restrictions on behavior to avoid conflicts.

\section{Deep Interdisciplinarity}

JSP was certainly not the only expression in the 1970s of the sense that the central role played by courts and rights legislation in questions of social policy should also be given a more central role in the university curriculum in general and law schools in particular. These included new schools of public policy at major universities, increased investment in law school based clinics to deliver legal services to hard pressed communities, and the law and economics movement. Selznick claimed to "accept the need to justify scholarship by searching appraisal of its policy worth." 31 In this respect JSP was an expression of the broader movements and associated with Law \& Society since the 1960s and with Legal Realism since the 1920s. But if JSP reflected those movements in its confidence that social science theory and methods could help to achieve a legal system more responsive to the needs of a modern democracy, it differed in its substantial commitment to the humanities and to history, cultural studies and philosophy. It is telling that Selznick is explicit that the humanities are not to be maintained in a kind of service role of honing writing and analytic skills within the pedagogy of the

30 For a fuller discussion of the varieties, potentials, and perils of such courts, see Allegra McCloud, Decarceration Courts: Possibilities and Perils of a Shifting Criminal Law, 100 Geo. L. J. (forthcoming).

31 Selznick, supra note 4, at 207. 
law school, but instead for their contribution to the "clarification of fundamental values." 32 It was Selznick's distinctive view (no doubt shared and influenced by Sanford Kadish) that such a move had to go along with a revitalization of that part of legal scholarship dealing explicitly with the fundamental nature of law and its foundations in morality and utility. Here again we see the importance of values to Selznick's sense of how the curriculum could unify normative, positive, and practical concerns. If values, like justice and democracy, are social facts crucial to understanding how law gets mobilized and with what effects, the research enterprise will require not only a sophisticated empirical methods, but sophisticated approach to conceptualizing intellectual history in a far broader sense of useful knowledge of all kinds than that term usually carries.

Likewise, while praising both the law and society movement, and the emerging law and economics movement for bringing the utilitarian critique of positive law to a greater level of sophistication, Selznick warned against the tendency toward technocracy in both. "The technocratic perspective celebrates efficiency but in doing so tends to slight intangible and long run effects." ${ }^{33}$ For Selznick the solution was to pursue empirical research into the practical effects of laws and procedures but to assure that "no line of inquiry, however 'technical,' is exempt from sustained evaluation of moral premises and moral effects." 34

It is, in retrospect, its commitment to intellectual breadth that makes Selznick's vision for JSP so unique and one of the reasons it remains largely unimitated. "The quest for intellectual breadth may exact some cost in intellectual coherence," Selznick noted with characteristic understatement. To the perennially insecure social sciences this cost is a very high one indeed. Economics has staked its claim to scientific and political status, largely on the precision of its core theoretical and methodological commitments, and disciplines like Political Science and Sociology seem eager to achieve the same apparent gains. ${ }^{35}$ The "disciplinary pride" and "disciplinary idiom" that an interdisciplinary program like JSP must be tolerant of have grown even more insular than they were in the 1970s when, in some respects, the behavioral sciences model encouraged more cooperation.

\section{2 lbid.}

33 lbid. at 214.

34 lbid.

35 As Thomas Kuhn documented in his landmark study of scientific revolutions, sciences which can normalize their practice and theory by promoting a dominant paradigm and shifting research toward the solution of incremental gap problems can gain periods of significant and rapid progress, at least until they come up against anomalies that the paradigm cannot account for. See, Thomas Kuhn, The Structure of Scientific Revolutions (1962). 
In the essay, Selznick identified two major strategies for combatting disciplinary insularity. The most important was a programmatic emphasis on core issues of jurisprudence, not in the sense of a broad agreement on the fundamental nature of law, but rather engagement around a set of fundamental questions about law. At the end of the 1970s these included the relationship between law and morality, the limits of individual rights on state power to achieve social ends like deterrence and victim compensation; but the specific questions were less important than that the work of the program "be informed by systematic attention to issues that are large in scope and high in priority."

In the original design of the JSP doctoral program this was imposed on the students through a requirement that they be examined as part of their qualifying exam on the "core of JSP," in addition to two fields of specialization. Just what the core consisted of was a subject of nervous speculation by all students and necessarily a topic of conversation between faculty and students. Large reading lists circulated that included the major contemporary figures in jurisprudence at the time including H.L.A. Hart, Ronald Dworkin, and Lon Fuller, as well as moral philosophers like John Rawls and Robert Nozick, constitutional theorists like John Hart Ely and Alexander Bickel, and social theorists like Roberto Unger, Catherine MacKinnon, and Selznick himself. In approximately 2000, the program was revised to eliminate the core requirement and replace it with a requirement that students pass qualifying exams in a field related to a discipline (like political science, sociology, or philosophy) and a topic field related to their eventual dissertation topic. The sense of the faculty at the time was that students would complete more efficiently and be better prepared for the job market by emphasizing disciplinary and topical goals. But while the loss of a core requirement may have diminished the intensity and frequency of discussions over fundamental questions of jurisprudence, they still arise in the topical field where disciplinary idioms to some extent must address broad issues of equity, justice, and due process, and in which at least two disciplinary perspectives must be evident. In the most recent program revisions, some move back toward the "core" is reflected in the requirement that all JSP students take a foundations seminar with a normative emphasis like moral or political philosophy.

A second tool for maintaining cohesion was what Selznick called "problem centered inquiry" which placed "the aspirations and frustrations of living people and living institutions" at the center of research rather than topics derived from the theoretical problems of the disciplines or the conceptualizations of law. In the 1970 s the obvious kinds of examples were desegregating schools, controlling police discretion, and protecting free speech in institutional settings like campuses. Selznick believed that a problem oriented approach would have the effect of integrating the program both across disciplines and between normative and empirical work: 
A problem-centered approach is both integrative and normative. It is integrative because it brings to bear every relevant intellectual resource. It is normative because it postulates a state of well-being in the light of which existing arrangements are to be assessed. I do not believe we thereby depart from scholarly objectivity or from the scientific ethos. Our normative models would be founded in inquiry regarding what people actually experience as deprivation and how institutions function in fact. ${ }^{36}$

Today this problem oriented cohesion is evident in the remarkably strong intellectual connections among Berkeley Law's criminal justice oriented faculty. While reflecting methodological and disciplinary perspectives ranging from econometrics to cultural criminology, the motivation to read each other's work has come from a shared sense that mass incarceration has produced catastrophic levels of distortion in American society while not delivering public safety in a sustainable and productive way. As Selznick would have expected, the tighter time frame and powerful perception of existing problems with the system have overwhelmed disciplinary mistrust and even epistemological gaps in the level of analysis or forms of valid data. As we look across Berkeley Law today, and most other major American law schools, one could identify any number of similar problem centered clusters. In these spaces many of the forces of fragmentation that keep apart scholars in the social sciences and humanities are temporarily suspended by the micro-physics created by the focus on practical institutions and consequences.

\section{Conclusion: Selznick's Vision and the Interdisciplinary Schools}

Buildings are not a bad metaphor (see Martin Krygier's contribution to this symposium for Selznick's own use of spatial metaphors) for the academic enterprises they house. JSP began life at the Center for the Study of Law \& Society, at 2240 Piedmont Avenue (to where the Center had moved from another in a row of large houses, once private residences and fraternities). While the law school was for the first time in American legal history acquiring not one or two but a faculty of social scientists and humanists (senior ones at that), they were still in a certain sense contained. As a student in both the JD and JSP programs, I could walk back and forth easily. The back doors were open and only steps apart but they still defined two worlds. Today the members of the far larger JSP faculty within the Berkeley Law faculty have dispersed. While a number remain in the house at 2240 by choice, in some of the most distinctive and handsome offices available, others

36 Selznick, supra note 4 at 214. 
are scattered throughout the school. More importantly, the scholarship is increasingly difficult to distinguish.

While Selnick's aspirations for the JSP program are ones that remain as marginal to the approach of the contemporary social science and humanities disciplines (for the most part) as they were in the 1970s, the contemporary law school pedagogy and scholarship has taken a decidedly Selznickian turn. As noted above across several dimensions, the features of the modest space Selznick was trying to carve out of the law school for JSP in the 1970s now characterize much of the broader field. Thus, while Selznick had to argue for a modest exception to the largely exclusive focus on positive law and procedures in the legal scholarship of the 1970s, and in favor of scholarship concerned with exploring the effects of law and the lived experience of people and institutions, the overall valence of legal scholarship (and to a lesser extent teaching) has shifted.

Today exclusively doctrinal scholarship is increasingly uncommon on the faculties of top tier law schools. Standard curriculum defined by legal doctrines now competes with a more problem centered curriculum anchored in clinics, research and policy centers. Not all of this scholarship and teaching would satisfy Selznick's high aspirations for what taking the lived experience of people and communities requires, but it no longer ignores that aspiration. Yet in two specific areas, Selznick's contrarian preferences within the interdisciplinary camp, for reorganization along problem centered lines, and for deep interdisciplinarity, offer the untapped potential to rationalize and integrate a law school curriculum that no longer self evidentially addresses its two specific tasks: (1) preparation of students for a broad range of practice careers, both at the bar and in various kinds of law/business, law/government, or law/social organization careers; and (2) preparation of future law teachers.

\section{(1) Practice careers}

The present economic crisis and the difficulties that some law graduates are facing in the market has heightened concerns that the new pedagogy and scholarship is insufficiently legal, but these criticisms often conflate doctrinal law with learning to "think like a lawyer," and assume that real world legal skills training would have as little as possible to do with the expanding interdisciplinary concerns of the legal scholarship. Both assumptions are mistaken. ${ }^{37}$ The growth

37 For a compelling case on both accounts see my colleague Kristen Holmquist, supra note 9. The Carnegie Commission's report, William Sullivan, Anne Colby, Judith Welch Wegner, Lloyd Bond \& Lee S. Shulman, Educating Lawyers: Preparation for the Profession of Law (2007), 
of skills curriculum and clinics across all levels of the American legal academy means that law students have far more access to classes and instructors able to connect them to real practice skills and institutions than ever before. Furthermore, doctrinal law always already represented a very different filtering of the legal field than many practice worlds rely on.

Yet the truth in the growing polemic against interdisciplinarity in legal education is that we have not yet produced a compelling account of the role of interdisciplinary faculty in producing an effective pedagogy. Selznick to his great credit never bought into any simple bipolar story about law, such as "law in action," versus "law in the books." Instead he embraced a very complex view of the nature of both books and action. If one must have a schema, the "four quadrants of jurisprudence" 38 presented by the late legal theorist Neil MacCormick of Edinburgh ${ }^{39}$ offered a more capacious and helpful framework, distinguishing "raw law," "doctrinal law," "law and social science," and "fundamental values and principals." Much of what people mean when they call for a pedagogy more relevant to launching students in practice careers amounts to a call for more courses in raw law, in what lawyers and judges actually do and how they do it. Doctrinal law, which brings a level of order and systematic coherence to the law absent in raw law, tracks closely to what faculty at law schools predominantly did in the 1970s and often requires significant distortion of the practical significance of law. Criminal law, which I regularly teach, is full of such distortions. Felony murder, for example, is regularly taught as a kind of archaic holdover of the common law's ignorance about mensrea, when in fact the doctrine developed legislatively for public policy reasons and has long been one of the most significant practical doctrines in the law of murder. ${ }^{40}$

Legal faculties today have an opportunity to draw on all four quadrants of law to revitalize law school pedagogy. "Raw law," which includes the lived experi-

suggested that law schools were by and large doing a good job teaching students to think like lawyers and doing an inadequate job of preparing them for the practical aspects of law.

Holmquist suggests that the report's embrace of the case method as a sound way to teach people to think like a lawyer is highly reactionary in its failure to grasp that thinking is actually at the heart of the practice skills the report rightly sees as under-supported.

38 Neil MacCormick, Four Quadrants of Jurisprudence, in W. Kravitz, G.H. von Wright, \& D.N. MacCormick, eds. Prescriptive Formality and Normative Rationality: Essays in Honour of R.S. Summers, 53-70 (1994).

39 Sir Neil MacCormick, 1941-2009, was the Regius Professor of Public Law and the Law of Nature and Nations at the University of Edinburgh, at various times a Member of the European Parliament for Scotland, and an officer of the Scottish National Party (SNP). MacCormick, who was struck down by cancer in 2009, was one of Europe's leading public intellectuals and the author of many significant works of jurisprudence and legal theory.

40 Guyora Binder, Making the Best of Felony Murder, 91 B. U. L. Rev. 403 (2011). 
ence of people before the law, can be brought into the classroom as never before through documentary and empirical methods. Doctrinal reforms can be tested against this more empirical version of "raw law" and subjected to analysis from the "law and social science", and the "fundamental values and principals" quadrants in a manner far more transparent and available for inquiry and disputation both as to their effects and their values. To some extent this is already reflected in the diversity of materials now wrapped around the appellate cases which remain the "main course" of $1^{\text {st }}$ year doctrinal courses. But if the menu is more diverse than ever, the age of interdisciplinarity has yet to produce a compelling account of how it belongs to a repertoire of interpretive, analytic, and communicative skills associated with lawyering. Selznick's problem centered pedagogy remain a project that could organize the curriculum. First year courses could remain largely defined along doctrinal areas but use problem centered case studies to integrate the curriculum, for example how a crime victim fares in criminal justice, but also as a possible tort claimant against not only the perpetrator but potentially responsible property owners and organizations; property owner or renter seeking protective orders in appropriate cases, and the civil procedure issues raised by civil protection orders.

\section{(2) The Doctoral Degree in Law? How should law professors be credentialed}

Surprisingly, law schools have also turned out to be promising spaces for the deep interdisciplinarity that Selznick advocated in his perspective and aspirations for JSP. Despite efforts at dominance by legal process scholars in the 1960s, and law and economics in the 1980s (the subject of Selznick's warnings about the technocratic thinking), the contemporary American law school is more diverse in the intellectual resources available within it than at any time in its history and more than any other location within the contemporary university. The doctoral degree has become a very helpful asset in the market for legal academic jobs, but not a requirement as it is in the social sciences and humanities. Meanwhile deep practice experience, once an unlikely path to teaching at higher tier law schools, is becoming more important.

This is perhaps a transitional moment, and some new orthodoxy will take root. But Selznick, a great student of the informal dynamics of organizations, may well have recognized that the very orientation toward practice and toward institutions like courts and agencies that made law schools seemingly resistant to academic forms of inquiry, also made them unlikely to be dominated by a single paradigm of research. Their outward orientation makes them inherently problem 
oriented, capable of appreciating the value of a wide range of knowledges but beholden to none of them. The unintended success of JSP graduates as candidates for law teaching positions suggests that the deep interdisciplinarity pushed by Selznick is a successful pedagogy for future law teachers.

JSP was never intended to provide a comprehensive graduate curriculum for future law teachers. Few in 1980 thought it would be necessary. The JD degree, refined through a few years of post-graduate experience, was deemed adequate graduate training for those whose performance in law school already indicated academic gifts. Today, law faculty positions increasingly require a graduate degree beyond the JD, or in some cases deep practice experience. While the doctorate is unlikely to become a requisite degree for law teaching, its advantages for academic competition mean that law schools will find themselves in the awkward position of importing their academics from other doctoral environments; mostly disciplinary departments like economics, political science, sociology or philosophy. In this mix, JSP represents an alternative path, a doctoral degree in law, anchored in the Ph.D. model of the disciplines, but tied to a commitment that students will engage with the fundamental problems of jurisprudence and problem based engagement with multiple disciplines.

In this expanded role, graduate education in law schools will need to face fundamental governance issues. In 1980 it was more a question of getting the receiving law school host body to accept the graft of $\mathrm{Ph} . \mathrm{D}$. holding disciplinary faculty with an interest in law. Today many, and perhaps most, of faculty in law schools have the credentials and may have the interest to play an active role in the production and governance of the doctoral program that will turn out the next generation of law teachers, and they should. Careful thought should be given to how to connect faculty teaching commitment to the graduate program and role in governance. This would have implications for appointments and the equitable allocation of teaching responsibilities. Those are not issues Selznick reckoned with in 1980. But the basic JSP model suggests the advantages of embracing the challenge of doctoral program in law rather than the model of balkanized JD+ programs with disciplinary departments that is the most likely competitor. 